УДК [6/3.2:37.091.212]-025.17

DOI: $10.15673 /$ fie.v10i4.1139

\author{
Свистун Т.В. \\ кандидат економічних наук, доцент \\ кафедра управління бізнесом \\ E-mail: svystuntatyana@gmail.com \\ Бєлошапко М.O. \\ студентка 5 курсу фракультету технології зерна і зернового бізнесу \\ Одеська національна академія харчових технологій \\ вул. Канатна, 112, м. Одеса, Україна, 65039 \\ E-mail: masha25555@gmail.com
}

\title{
УПРАВЛІННЯ ХАРЧОВИМ ВИБОРОМ СТУДЕНТСЬКОЇ МОЛОДІ
}

Важливою складовою здорового способу життя є раціональне харчування, яке допомагає підтримувати високий рівень життєдіяльності. Стаття присвячена аналізу харчування студентів вищої школи, визначення акцентів формування свідомого ставлення до харчування як фрактора збереження здоров'я і високої працездатності. Проведено розрахунок вартості «Тарілки здорового харчування» для студентів. Проведено аналіз даних сучасної наукової літератури з проблеми впливу харчування на стан здоров'я студентів. Виявлено низький рівень вмінь і навичок студентів в організації власного харчування. 3'ясовано, що більша частина студентської молоді не звертає увагу на калорійність, енергетичну цінність харчового раціону, що призводить до зниження працездатності та поганого самопочуття. Запропоновано шляхи підвищення рівня знань з практичної нутріціології студентів вищої школи як ефективної умови покращання стану їхнього здоров'я.

Ключові слова: харчування, здоров'я, студенти, здорове харчування, споживачі, збалансоване харчування.

This work is licensed under a Creative Commons Attribution 4.0 International License http://creativecommons.org/licenses/by/4.0/

Постановка проблеми та її зв'язок з важливими науковими та практичними завданнями. Важливу роль у забезпеченні якості життя людини, його фізичного і психічного здоров'я, тривалості життя грає раціональне харчування. Воно, разом $з$ фізичною активністю, відноситься до елементів повсякденної поведінки, що формує здоров'я людини. [1, с. 24]

Підготовка майбутніх фахівців у ЗВО містить в собі не тільки професійне навчання, а й формування світогляду громадянина, що має принципи здоров'я зберігає поведінки, бо відсутність останніх призводить до цілого ряду суспільно небезпечних негативних тенденцій, зокрема, до зростання захворюваності й смертності. Однією з основних та великих проблем сучасної молоді являється стан збалансованості та корисності їх харчування. Здорове та збалансоване харчування дозволяє забезпечити ефективний розвиток організму молоді. Очевидно, що оптимізація харчування $\epsilon$ не тільки медичною, а й соціальною проблемою.

Аналіз останніх публікацій по проблемі. Вивченням вибору споживачами харчової продукції та вивченням ризиків погіршення здоров'я, пов'язаного зі споживанням продуктів харчування, займаються багато зарубіжних дослідників, розглядаючи дану проблему 3 різних точок зору. У літературі представлені наступні напрямки досліджень: вивчення стратегій поведінки споживачів, їх сприйняття ризиків, пов'язаних зі споживанням харчових продуктів (Baker i Burnham, Loureiro, McCluskey, Mittelhammerare та ін.); дослідження впливу механізмів державної політики щодо безпеки харчових продуктів (наприклад, сертифікація, ліцензування, маркування та ін.) (Gruere, Carter, Farzin; Starbird; Baker, Armstrong); вивчення стратегій поведінки виробників на ринку продуктів харчування (Thomsen, McKenzie; Moorman; Shapiro).

В Україні багато науковців досліджують проблему здорового харчування це: Гойчук А., Власов В., Денисенко Л., Смірнова І., Передерій В., Григоров Ю, та інші. Матеріали досліджень і публікацій показують, що у більшості населення порушений режим харчування. У стравах переважають дешеві продукти з низькою біологічною цінністю, недостатнім $є$ споживанням м'ясних, молочних, рибних продуктів, овочів і фруктів.

В результаті неповноцінного харчування в Україні вдвічі зросла захворюваність населення на ендокринні хвороби, розлади харчування та порушення обміну речовин, спостерігається виразна тенденція до набирання зайвої маси тіла та поширення ожиріння, значне поширення хвороб системи кровообігу, онкологічних захворювань.

За останні 10 років захворюваність серед студентів збільшилася на $35 \%$. Однією 3 основних причин цієї тенденції $є$ нераціональне харчування. Отже, розкриття теми має актуальне значення. 
Формулювання цілей дослідження. Метою статті $\epsilon$ аналіз стану харчування студентської молоді як фактора збереження здоров'я і високої працездатності. Завданням дослідження була діагностика вміння студентів визначати та оцінювати свої харчові звички; встановити залежність між характером харчування та рівнем працездатності та здоров'я; виявити, що впливає на нераціональне харчування студентів; дослідити, що є основним джерелом інформації про оптимальне харчування.

Виклад основних результатів та їх обгрунтування. Існують два типи порушення харчування. Перший пов'язаний з обмеженістю асортименту продуктів і дефіцитом в їжі необхідних структурних, енергетичних та біологічно активних речовин (білки, жири, вуглеводи, вітаміни, мінерали та ін.). Другий перш за все 3 невмінням правильно харчуватися, 3 відсутністю елементарних знань і культури харчування. [2]

В Україні актуальність проблем, пов’язаних 3 якістю та характером харчування студентів, визначається низькою спроможністю більшості сімей у забезпеченні повноцінного харчового раціону, стійкими порушеннями структури харчування.
3 метою дослідження доступності раціонального харчування для студентів, ми провели розрахунок вартості «Тарілки здорового харчування», яка була презентована 13 грудня 2017 р. Міністерством охорони здоров'я разом із Центром громадського здоров'я та експертами-дієтологами в якості національних рекомендацій зі здорового харчування, що визначає найважливіші групи продуктів, які повинні входити до щоденного раціону людини. [3] До складу рекомендованих продуктів увійшли сезонні овочі та фрукти, звичні та доступні молочні та кисломолочні продукти, різні види риби та м'яса.

По-перше, ми провели аналіз вартості рекомендованих продуктів за пропозиціями торгових мереж і обрали найбільш дешеві продукти з запропонованих в кожній групі «Тарілки здорового харчування». Вода з бювету - безкоштовно.

По-друге, ми склали таблицю «Вартість тарілки здорового харчування» в якій надали інформацію щодо добової рекомендованої норми продуктів, цін на рекомендовані продукти (табл.1). На основі цієї інформації ми розрахували вартість щоденного раціону за день та місяць.

Вартість тарілки здорового харчування (найдешевший варіант)*

\begin{tabular}{|l|c|c|c|}
\hline \multicolumn{1}{|c|}{ Продукт } & Добова норма & Ціна за 1 кг, грн & Вартість, грн \\
\hline гречка & 100 г & 15 & 1,5 \\
\hline капуста білокачанна & 100 г & 7 & 0,7 \\
\hline морква & 100 г & 9 & 0,9 \\
\hline буряк & 100 г & 6 & 0,6 \\
\hline хек & 100 г & 100 & 10 \\
\hline курятина (філе) & 100 г & 110 & 11 \\
\hline яйця & 2 шт & 28 (за 10 шт) & 5,6 \\
\hline соняшникова олія & 70 г & 32 & 2,24 \\
\hline молоко & 0,5 л & 24 & 12 \\
\hline кефір & 0,5 л & 26 & 13 \\
\hline яблуко & 150 г & 13 & 1,95 \\
\hline банан & 150 г & 24 & 3,6 \\
\hline насіння гарбуза & 15 г & 200 & 3 \\
\hline волоські горіхи & 15 г & 300 & 70,59 \\
\hline За день & \multicolumn{3}{|l}{} \\
\hline За місяць & \multicolumn{2}{l}{} \\
\hline
\end{tabular}

*Розраховано авторами на основі джерел [3]

Для порівняння, ми розрахували також варіант «Вартості тарілки здорового харчування», що складається з більш дорогих продуктів (табл.2).

Отже, найдешевша «корисна тарілка», до якої увійдуть 7 здорових страв, обійдеться в 70,59 грн. в день, або до 2117,7 грн /міс, за умови, що студенти будуть самостійно готувати собі їж, а не користуватись послугами закладів харчування.

Якщо порівняти цю суму з розміром стипендії для студентів вищих навчальних закладів III - IV рівня акредитації - 1180 гривень [4], стає очевидним, що здорове харчування є малодоступним для студентів.

Згідно досліджень ЮНІСЕФ, проведених в рамках міжнародного проекту «Здоров'я та поведінкові орієнтації молоді», респондентам було запропоновано суб'єктивно оцінити адекватність свого харчування за показником маси тіла. З'ясувалося, що $69,3 \%$ опитаних вважають свою масу нормальної, 17,7 - надлишкової, 11,9\% - недостатньою. 
Таблиця 2

Вартість тарілки здорового харчування (більш дорогі продукти)*

\begin{tabular}{|c|c|c|c|}
\hline Продукт & Добова норма & Ціна за 1 кг, грн & Вартість, грн \\
\hline булгур & 100 г & 27 & 2,7 \\
\hline брокколі & 100 г & 100 & 10 \\
\hline баклажани & 100 г & 60 & 6 \\
\hline томати & 100 г & 30 & 3 \\
\hline судак & 100 г & 160 & 16 \\
\hline курятина (філе) & 100 г & 110 & 11 \\
\hline яйця & 2 шт & 28 (за 10 шт) & 5,6 \\
\hline оливкова олія & 70 г & 150 & 10,5 \\
\hline молоко & 0,5 л & 24 & 12 \\
\hline йогурт & 0,5 л & 26 & 13 \\
\hline яблуко & 150 г & 13 & 1,95 \\
\hline банан & 150 г & 24 & 3,6 \\
\hline насіння гарбуза & 15 г & 200 & 3 \\
\hline Мигдаль & 15 г & 600 & 9 \\
\hline \multicolumn{3}{|l|}{ За день } & 107,35 \\
\hline \multicolumn{3}{|l|}{ За місяць } & 3220,5 \\
\hline
\end{tabular}

*Розраховано авторами на основі джерел [3]

Іншими словами, суб'єктивно третина студентів оцінюють свою масу як незадовільну [5].

Аналіз кратності прийомів їжі студентів показав, що лише $19,7 \%$ респондентів харчуються 4 рази на день, більшість опитаних $(42,4 \%)$ приймають їжу 3 рази в день, а 29,0\% - тільки 1-2 рази. Третина $(32,0 \%)$ учасників дослідження зізналися, що вони не снідали в день опитування. 8,7\% респондентів відзначили занадто частий прийом їжі (5-7 разів), що говорить про присутність додаткових прийомів їжі, які або рівномірно розподілені в часі протягом дня або заміщають один з основних прийомів їжі.

В ході опитування було з'ясовано, що $66,0 \%$ студентів вважають за краще на сніданок чай або каву з бутербродами і тільки 20,0\% мають повноцінний сніданок. Переважна більшість респондентів (80,0\%) зазначили, що вечеряли напередодні, 3 них 16,0\% зізналися, що їли за 1 годину до сну, що може свідчити про відсутність у студентів фіксованого часу прийому їжі.

Аналіз відповідей на питання «Які продукти переважають у Вашому раціоні?» Показав, що 63,3\% учасників опитування віддають перевагу овочам, фруктам і продуктам його $(33,9 \%$ серед овочів за краще картопля, який є в більшій мірі джерелом вуглеводів). На другому місці стоять хлібобулочні і борошно-круп'яні вироби (49,8\% респондентів). М'ясо та м'ясні продукти переважають в раціоні 48,4\% опитаних, молоко і молочні продукти - 27,8, риба і продукти моря - 26,1, цукор і кондитерські вироби $26,8 \%$.

Відповідаючи на більш певне питання «Скільки разів на тиждень Ви вживаєте той чи інший продукт?», студенти зізналися, що досить регулярно їдять молочні продукти - 25,0\%, куряче м'ясо - 29,1, яйця курей - 21,1\%. 26,6\% вважають основним м'яс- ним продуктом ковбасні вироби, і абсолютна більшість $(87,2 \%)$ вважають за краще жирну їжу. Щодня їдять свіжі фрукти та овочі менше половини $(43,0 \%)$ опитаних. Борошняні продукти та солодощі щодня переважають у раціоні понад дві третини респондентів $(72,5 \%)$. Очевидним є факт дефіциту в раціоні студентів продуктів, які є основними джерелами повноцінного білка, і переважання вуглеводно-жировий їжі.

3 напоїв більше третини опитаних $(36,0 \%)$ віддають перевагу чаю і каві, 26,0 - мінеральній воді, $18,8 \%$ - соку і компотам. Чверть респондентів $(25,0 \%)$ щотижня вживають пиво та інші алкогольні напої, 9,2\% - роблять це 3-4 рази на тиждень [6].

Понад половину респондентів $(51,0 \%)$ розуміють, що їхнє ставлення до харчування не дозволяє бути здоровим, при цьому переважна більшість $(87,0 \%)$ згодні з твердженням, що правильне харчування може зберегти здоров'я. Своє нераціональне і нездорове харчування $61,7 \%$ студентів пов'язують 3 браком часу, коштів і неорганізованим режимом дня; $19,7 \%$ - не замислювалися над цим питанням або не вважають за потрібне їм займатися, а 1,6\% упевнені, що здорове харчування не може бути смачним.

Анкетування показало, що основним джерелом інформації про оптимальне харчування для чверті опитаних $(26,8 \%) є$ засоби масової інформації, зокрема реклама; п'ята частина студентів $(21,8)$ дізнаються про правильне харчування від членів сім'ї та знайомих, і тільки $16,0 \%$ молодих людей звертаються 3 цим питанням до медичних працівників і спеціальній літературі [7].

Оскільки згідно досліджень більшість опитуваних основним джерелом інформації про харчування назвало рекламу, ми звернулись до досліджень реклами. Проаналізувавши відеоролики, у яких головні 
герої мали на вигляд студентський вік, які в транслюються на українських телеканалах, ми побачили, що в більшості випадків рекламується їжа та напої. У категорію «їжа» потрапили ролики, які в більшості випадків рекламують: ресторани швидкого харчування, чіпси, сухарики, морозиво, жуйки, шоколад та цукерки, кетчуп, сухі сніданки. У категорію «напої» потрапили солодкі газовані напої, сік, кава, пиво, слабоалкогольні напої.

Як бачимо, ідеться передусім про «швидку», готову до споживання їжу, пиво та слабоалкогольні напої. Раціон із перерахованих продуктів важко назвати здоровим, тим не менш саме такі продукти й напої пропонуються молоді в телерекламі й загалом подаються як «молодіжні».

Що стосується наступної групи студентів, які дізнаються про правильне харчування від членів сім'ї і знайомих, то слід зазначити, що стан здоров'я дорослого населення України можна характеризувати як незадовільний. Висока захворюваність і смертність дорослого населення, висока дитяча смертність, низька тривалість життя - ось ті показники, які визначають стан здоров'я української нації. При розгляді структури смертності в цілому стає очевидним, що іiі основними причинами є хвороби кровообігу і рак. Це свідчить в тому числі й про неприпустимо низький рівень освіти населення з питань здорового, раціонального та лікувально-профілактичного харчування. $[8,9]$

Першим важливим кроком для вирішення проблеми раціонального харчування $є$ формування мотивації молоді до збереження власного здоров'я, виховання почуття відповідальності за власне здоров'я. Другим кроком має стати поширення знань щодо формування здорового способу життя в молодіжному середовищі. Це потрібно робити, перш за все, за ра- хунок переорієнтації системи пропаганди із вивчення впливу негативних факторів поведінки на показ переваг, які забезпечує здоровий спосіб життя. Третім кроком має стати засвоєння цих знань і необхідних навичок, що уможливить свідоме ставлення молоді до власного здоров'я та до здоров'я людей із соціального оточення. [10, с 39]

Так, наприклад, в Одеській національній академії харчових технологій організовано всеукраїнську науково-практичну конференцію молодих учених та студентів 3 міжнародною участю "Проблеми формування здорового способу життя у молоді". Питання забезпечення доступного здорового харчування в межах навчального закладу може вирішити «Навчальний ресторан 112».

Висновки та перспективи подальших досліджень. Отже, у нашому суспільстві існує гостра соціальна проблема, пов'язана 3 нераціональним харчуванням української студентської молоді, що потребує детального аналізу, розроблення нових підходів до формування ціннісних орієнтацій молоді щодо харчування. В результаті проведених в статті досліджень ми бачимо, що на нераціональне харчування студентів впливає: низький рівень доходів населення; низький рівень знань щодо здорового харчування; рекламна пропаганда нездорової їжі. Теоретичне значення дослідження полягає в розвитку наукових положень щодо управління харчовим вибором студентів на засадах збалансованого харчування. Практичне значення даного дослідження полягає в тому, що воно буде використане нами для обгрунтування проекту управління інноваційним розвитком закладу харчування, призначеного для студентів. Перспективою подальших досліджень $є$ розроблення шляхів впливу на харчовий вибір студентів 3 метою формування здорового способу життя.

\section{Література}

1. Всесвітня організація охорони здоров'я. План дій в галузі харчових продуктів і харчування на 20152020 рр. Ел. ресурс. URL: http://www.euro.who.int/ru/about-us/governance/regional-committee-for-europe/pastsessions/64th-session/documentation/working-documents/eurrc6414-european-food-and-nutrition-action-plan-

20152020 (дата звернення: 30.10.2018).

2. Лукащук-Федик С.В. Безпека життєдіяльності: навчальний посібник для студентів вищих закладів освіти України I-IV рівнів акредитації. Тернопіль: ТНЕУ, 2015. 267 с.

3. МО3 України представило рекомендації зі здорового харчування. Ел. ресурс. URL: http://moz.gov.ua/article/news/moz-ukraini-predstavilo-rekomendacii-zi-zdorovogo-harchuvannja (дата звернення: 30.10.2018).

4. Стипендія 2018: розмір соціальних i академічних виплат. Ел. ресурс. URL: https://www.lawportal.com.ua/stipendija-rozmir-socialnih-akademichnih-viplat.html (дата звернення: 30.10.2018).

5. О.М. Балакірєва, Т.В. Бондар, Д.М. Павлова та ін. Показники та соціальний контекст формування здоров'я молоді // моногр. К.: ЮНІСЕФ, Укр. ін-т соц. дослідж. ім. О. Яременка. К., 2014. С. 156. Ел. ресурс. URL: http://www.unicef.org/ukraine/ukr/Analitical_report_HBSC_2015_Internet.pdf (дата звернення: 21.10.2018).

6. Презентація результатів дослідження проекту «Здоров’я та поведінкові орієнтації молоді». О. Яременко. К., 2014. Ел. ресурс. URL: http://www.uisr.org.ua/img/upload/files/presentation14_HBSC_2014_28_05_2015_fin.pdf (дата звернення: 21.10.2018).

7. Гриньова М. Роль збалансованого харчування у забезпеченні здорового способу життя студентства. Наукові записи: педагогічні науки. 2014. №131. С. 3-5.

8. Горобей М.П. Проблеми збалансованого харчування студентів. Педагогіка, психологія та медикобіологічні проблеми фізичного виховання і спорту. 2011. №10. С. 20-22. 
9. Замойська К. Раціональне харчування студентів - запорука їхнього здоров’я. Вісник ЦдПУ ім. В.Винниченка. 2014. №5. URL: https://www.cuspu.edu.ua/ua/71-naukovi-konferentsii-tsdpu/2014/-4-5-6/1292racionalne_xarchuvannya_studentiv_\%E2\%80\%93_zaporuka_\%D0\%87xnogo_zdorov\%E2\%80\%99уа (дата звернення: 30.10 .2018$)$

10. Здоров'я - 2020: основи Європейської політики на підтримку дій всієї держави і суспільства в інтересах здоров'я і благополуччя. Копенгаген: Свропейське регіональне бюро ВООЗ. 2012 р.

Стаття надійшла 2.11.2018

Стаття прийнята до друку 16.11.2018

Доступно в мережі Internet 29.12.2018

Свистун Т.B.

кандидат экономических наук, доцент

кафедра управления бизнесом

E-mail: svystuntatyana@gmail.com

Белошапко М.O.

студентка 5 курса фракультета технологии зерна и зернового бизнеса

Одесская национальная академия пищевых технологий

ул. Канатная, 112, м. Одеса, Украина, 65039

E-mail: masha25555@gmail.com

\section{УПРАВЛЕНИЕ ПИЩЕВЫМ ВЫБОРОМ СТУДЕНЧЕСКОЙ МОЛОДЕЖИ}

Важной составляющей здорового образа жизни является рациональное питание, которое помогает поддерживать высокий уровень жизнедеятельности. Статья посвящена анализу питания студентов высшей школы, определения акцентов формирования сознательного отношения к питанию как фрактора сохранения здоровья и высокой работоспособности. Проведен расчет стоимости «Тарелки здорового питания» для студентов. Проведен анализ данных современной научной литературы по проблеме влияния питания на состояние здоровья студентов. Выявлен низкий уровень умений и навыков студентов в организации собственного питания. Показано, что большая часть студентов питаются малопитательных продуктами быстрого приготовления. Очевидным является фракт дефицита в рационе студентов продуктов, которые являются основными источниками полноценного белка, и преобладание углеводно-жировой пищи. Недостаточный уровень знаний о надлежащем питанием является потенциальным фактором ухудшения здоровья. Особое внимание уделено необходимости сбалансированного и рационального питания как основного фризиологического фрактора укрепления здоровья молодого человека. Выяснено, что большая часть студенческой молодежи не обращает внимание на калорийность, энергетическую ценность пищевого рациона, что приводит к снижению работоспособности и плохого самочувствия. Доказана важность и необходимость использования сбалансированного питания в практике здорового образа жизни студентов. Установлено, что одной из приоритетных задач сегодня является повышение уровня образования студенческой молодежи по вопросам здорового питания. Проведенное анкетирование показало, что основным источником информации об оптимальном питании является реклама о «быстрой», готовой к употреблению пища, пиво и слабоалкогольные напитки. Такие продукты и напитки предлагаются молодежи в телерекламе и вообще подаются как «молодежные». Выявлено, что на нерациональное питание студентов влияет: 1) низкий уровень доходов населения; 2) низкий уровень знаний по здоровому питанию; 3) рекламная пропаганда нездоровой пищи. Предложены пути повышения уровня знаний с практической нутрициологии студентов высшей школы как эффективное условие улучшения состояния их здоровья.

Ключевые слова: питание, здоровье, студенты, здоровое питание, потребители, сбалансированное питание.

\section{Svistun T.}

Ph.D., Associate Professor

Department of Business Management

E-mail: svystuntatyana@gmail.com

Beloshapko $\mathbf{M}$.

The student of the fifth grade of the Faculty of Technology of Grain and Grain Business

Odessa National Academy of Food Technologies

Kanatna str., 112, Odesa, Ukraine, 65039

E-mail: masha25555@gmail.com

\section{FOOD CHOICE MANAGEMENT OF STUDENT YOUNG PEOPLE}

An important component of a healthy lifestyle is a balanced diet that helps maintain a high level of vital activity. The article is devoted to the analysis of nutrition of high school students, the definition of empha 
sis on the formation of a conscious attitude to nutrition as a factor in maintaining health and high capacity for work. The calculation of the cost of "plates of healthy nutrition" for students has been carried out. The analysis of the data of modern scientific literature on the problem of the effect of nutrition on the health of students has been carried out. A low level of skills of students in the organization of their own food has been revealed. It has been shown that most of the students eat low-nutrition fast food. The fact of the lack of foods that are the main sources of high-grade protein, in the student's diet and the predominance of carbohydrate and fatty foods is obvious. Lack of adequate nutritional knowledge is a potential factor of poor health. Particular attention is paid to the need for a balanced and rational nutrition as the main physiological factor in promoting the health of a young person. It was found that a large part of the student youth does not pay attention to the calorie content, energy value of the diet, which leads to a decrease in efficiency and poor health. The importance and necessity of using a balanced diet in the practice of healthy lifestyle of students has been proved. It has been established that one of the priority tasks today is to increase the level of education of students in the field of healthy nutrition. The survey has shown that the main source of information about optimal nutrition is an advertisement about "fast", ready-to-eat food, beer and low-alcohol beverages. Such foods and drinks are offered to young people on television and are generally served as "youth." It has been revealed that the inefficient nutrition of students is affected by: 1) low income level of the population; 2) low level of knowledge on healthy nutrition; 3) advertising promotion of junk food. The ways of increasing the level of knowledge on the practical nutritiology of high school students as an effective condition for improving their health have been proposed.

Key words: nutrition, health, students, healthy eating, consumers, balanced nutrition.

\section{References}

1. Vsesvìtnâ organìzaciâ ohoroni zdorov'â. Plan dìj v galuzì harčovih produktìv ì harčuvannâ na 2015-2020 rr. (2014). Retrieved October 30, 2018, from http://www.euro.who.int/ru/about-us/governance/regional-committee-foreurope/past-sessions/64th-session/documentation/working-documents/eurrc6414-european-food-and-nutrition-actionplan-20152020

2. Lukashchuk-Fedyk, S. V. (2015). Bezpeka žittêdiâl'nostì. Ternopil: TNEU.

3. MOZ Ukraïni predstavilo rekomendaciï zì zdorovogo harčuvannâ. (2017). Retrieved October 30, 2018, from http://moz.gov.ua/article/news/moz-ukraini-predstavilo-rekomendacii-zi-zdorovogo-harchuvannja

4. Stipendiâ 2018: Rozmìr socìal'nih ì akademičnih viplat. (2018). Retrieved October 30, 2018, from https://www.lawportal.com.ua/stipendija-rozmir-socialnih-akademichnih-viplat.html

5. Balakirieva, O. M., Bondar, T. V., \& Pavlova, D. M. (2014). Pokazniki ta social'nij kontekst formuvannâ zdorov'â molodì. Kyiv: ÛNİSEF, Ukr. ìn-t soc. doslìdž. ìm. O. Yaremenka. Retrieved October 21, 2018, from http://www.unicef.org/ukraine/ukr/Analitical_report_HBSC_2015_Internet.pdf

6. Prezentaciâ rezul'tatìv doslìdžennâ proektu «Zdorov'â ta povedìnkovì oriêntaciï molodì». O.Yaremenko. (2014). Retrieved October 21, 2018, from http://www.uisr.org.ua/img/upload/files/presentation14_HBSC_2014_28_05_2015_fin.pdf

7. Hrynova, M. (2014). Rol' zbalansovanogo harčuvannâ u zabezpečennì zdorovogo sposobu žittâ studentstva. Naukovì Zapisi: Pedagogični Nauki, (131), 3-5.

8. Horobei, M. P. (2011). Problemi zbalansovanogo harčuvannâ studentìv. Pedagogika, Psihologiâ Ta Medikobiologični Problemi Fìičnogo Vihovannâ i Sportu, (10), 20-22.

9. Zamoiska, K. (2014). Racìonal'ne harčuvannâ studentìv - zaporuka ïhn'ogo zdorov'â. Vìsnik CDPU ìm. V.Vynnychenka, (5). Retrieved October 30, 2018, from https://www.cuspu.edu.ua/ua/71-naukovi-konferentsiitsdpu/2014/-4-5-6/1292-racionalne_xarchuvannya_studentiv_-_zaporuka_Ïxnogo_zdorov’ya

10. Zdorov'â - 2020: Osnovi Êvropejs'kö̈ politiki na pidtrimku dìj vsiêi deržavi ì suspil'stva vinteresah zdorov'â ì blagopoluččâ. (2012). Kopenhahen: Êvropejs'ke regìonal'ne bûro VOOZ.

Received 2 November 2018 Approved 16 November 2018 Available in Internet 29.12.2018

Цитування згідно ДСТУ 8302:2015

Свистун Т.В., Бєлошапко М.О. Управління харчовим вибором студентської молоді // Економіка харчової промисловості. 2018. Т.10, вип. 4. С. 110-115. doi: 10.15673/fie.v10i4.1139

Cite as APA style citation

Svistun T., \& Beloshapko M. (2018). Food choice management of student young people. Food Industry Economics, 10(4), 110-115; doi: 10.15673/fie.v10i4.1139 